\title{
Effectiveness of Law Enforcement on Mining Crime Without Permission (PETI) in Wonosobo
}

\author{
Budi Raharjo ${ }^{1}$
}

Abstract. The background of this research is the rampant mining without permission (PETI) due to the mindset of society or mining entrepreneur who is not based on the exploitation of environmental awareness that will have lasting impact on the next generation. This journal aims to analyze the effectiveness of law enforcement on mining crime without permission in Wonosobo. The method used in the form of in-depth case studies, explores and elaborates on PETI mining case. While the documents studied are the Investigation Report of PETI crime suspection in Wonosobo. The analysis is concerned with the investigation of cases of PETI facts in violation of Article 158 of the Mining Act. The results of the research community was not aware of the law related to the licensing of mining, proved the existence of dredging sand in the suspect area, but the mining business is not licensed. The author suggests the socialization of law and public law for the voluntary movement of miners, so a realization that a legal substance in the Mining Act can be used as a means of protecting the public with government and environmental sustainability.

Keywords: Effectiveness; Law Enforcement; Mining Crime Without Permission.

\section{Introduction}

Mining without permission (PETI) is the problem of mining practices which is not expected by all parties. Government authorities set and manage mining in Indonesia is concerned that the practice of mining does not lead to environmental damage. Meanwhile law enforcement authorities, as well as the functions inherent in the role of enforcement law, the problem of PETI do not keep mushrooming in the community. In addition, as the legal basis for action against activities PETI, then the investigator Police maintain order and the rule of law in an effort to apply the substance of law as stipulated in Article 158 of the Law of the Republic of Indonesia Number 4 of 2009 on Mineral and Coal Mining (hereinafter called Act of Minerba). This legal law interesting to study how far the implementation of this environmental criminal offense be able to order the remedy which people who do PETI.

PETI bloom and become one of the foundation of economic resources of society on the pretext that the mineral and coal resources are natural resources and can be sold directly into money. ${ }^{1}$ Convenience is not based on a way of thinking and consciousness of society and or mining entrepreneurs found ways to exploit the environment with long-term impact generations to come. For the sake of the stomach needs today, they gave up the right to enjoy the grace of nature and the environment for future generations.

Constitution (law) mandates that the management of natural resources dominate the life of the people, must be environmentally and environmental ethics that promote sustainability, ecosystem sustainability and environmental capacity in the future. ${ }^{2}$

\footnotetext{
${ }^{1}$ Students Master Program (S2) of Law UNISSULA email: budirahario2811@yahoo.com
} 
The effectiveness of law enforcement in environmental crime coupled with public demand for mineral and coal mining without permission worth analyzing and look for the root cause of the problem of PETI growing of late.

This journal aims to analyze the effectiveness of law enforcement criminal offense mining without permission in Wonosobo. The analytical method used is the use of PETI cases in Wonosobo were successfully investigated by the police who had documented in the Dossiers PETI as criminal acts. Thus this paper uses two things: a case study and document as an approach to review, parse and analyze the problems of the crime of mining without permission, Reasonable expectation embedded in this journal is the new idea that is able to measure the effectiveness of law enforcement of PETI as criminal acts.

\section{Research Methods}

There is a fundamental question in this journal which need to reply, namely the extent to which the effectiveness of law enforcement criminal offense mining without permission in Wonosobo? To analyze the problem, the writer uses the case study method, which is about to understand the phenomenon of PETI as criminal acts in depth, even explored and elaboration ${ }^{3}$. While the documents studied are the Investigation Report Mining crime suspection without permission in Wonosobo. Analysis of the authors emphasized the fact investigation of cases of PETI violation of Article 158 on Mining Act.

\section{Results And Discussion}

\subsection{Research (Case Study of Case Holds of PETI)}

In this paper cases studied are Police Report No. P / A / 445 / IX / 2017 / Java / DIT Reskrimsus dated 25 September 2017 regarding the alleged criminal act of mining without permission, Meanwhile, the authors analyzed the document title document in the case of the case. As has become part of the management of the investigation of the case, the results of this study follow the given format, by adjusting the writing systematic document.

Anatomy Case:

- Case

Alleged criminal offense conduct mining operations without a Mining Business License (IUP), People's Mining Permit (IPR) or Special Mining Business License (IUPK), as referred to in Article 158 of Law of the Republic of Indonesia Number 4 of 2009 on Mineral and Coal Mining.

- Reported / Suspect: Br. HW Bin SM (Alm).

- Time and Place Event Case

\footnotetext{
${ }^{2}$ Ahmad Redi "The Dilemma of Law Enforcement Mineral and Coal Mining Without Permission on SmallScale Mining (Dilemma of Law Enforcement Illegal in Small Scale Mining) " Journal Rechts Vinding National Legal Development Media Volume 5 No. 3 (2016),http://rechtsvinding.bphn.go.id/artikel/ART\%207\%20JRV\%205.3\%20WATERMARK.pdf, ${ }^{3}$ Yin Robert K 1994 CASE STUDY RESEARCH. Thousand Oaks London New Delhi: SAGE Publications $\mathrm{p} 21$.
} 
On Wednesday August 24, 2017, in Bedakah, Telogomulyo Village, Kertek District, Wonosobo

- Chronological Case

On Wednesday, August 24, 2017, a team of Unit 1 Subdit IV Central Java Police Ditreskrimsus together - together with the attendant EMR Central Java province to investigate mining activities are in Bedakah, Telogomulyo Village, Kertek District, Wonosobo. After officers arrived at the site, acquired the land settlement activities are ongoing using one (1) unit of the brand excavators KOBELCO SK 200 with green colour. By the time the officer conduct an examination of the land settlement activities, acquired the activities of the sand filling of the excavator into a bath truck. Where most materials from mining activities were sold to the general public. Further evidence in the form of 1 (one) unit Excavator Brand KOBELCO SK 200 with green colour is secured by officers and entrusted to the Office of Regional BP3SDM South Serayu for further investigation.

- Evidence :

- 1 (one) unit Excavator Brand KOBELCO SK 200 green.

- 3 (three) ritase record book.

- Article which presupposed

Article 158 of Law - Law of the Republic of Indonesia Number 4 of 2009 on Mineral and Coal Mining.

The case above is a criminal act of mining without permission which occurred in Wonosobo. Exposure to these data suggests that: The suspect was conducting land arrangement which, according to witness testimony is the activity of dredging sand and rock that is fed into a dump truck. Another witness who acted as driver, Excavator testified that these activities are dredging sand and put it into dump trucks, on land owned by the suspect.

Mining without incident a criminal offense permission it is known from mining investigations on site Genesis Case (TKP), which involves a team of Unit 1 Subdit IV Central Java Police Ditreskrimsus together with the attendant EMR Central Java Province.

Evidence found is 1 (one) unit Excavator Brand KOBELCO SK 200 with green colour and three (3) notebook of ritase.

The suspect was suspected of committing the crime of mining without permission (PETI) that the offense formulated in Article 158 Mining Act.

According to the author, is interesting to examine the case from the perspective of Article 158 Mining Act. In Chapter XXIII Mining Act regulates the Criminal Provisions. While Article 158 is the first chapter in the chapter. Juridical formulation Mining Act Article 158 as follows: "Anyone who does mining without IUP, IPR or IUPK as referred to in Article 37, Article 40 paragraph (3), Article 48, Article 67 paragraph (1), Article 74 paragraph (1) or subsection (5) shall be punished with imprisonment of ten (10) years and a fine of 10,000,000,000.00 (ten billion rupiah). "

Article 158 is a derivative of Article genus chapter are:

- Article 37 "IUP is given by: a) regent / mayor if WIUP are in one district / city; b) governor if WIUP in inter districts / cities within 1 (one) province after getting a recommendation from regents / mayors in accordance with the local laws and 
regulations; and cMinister when WIUP are at cross-province after getting a recommendation ) from the governor and regent / mayor in accordance with the local laws and regulations."

- Article 40 paragraph (3) : "(3) IUP intending to commercialize other minerals referred to in paragraph (2), shall submit new IUP petition to the Minister, governors and regents / mayors in accordance with their authority. "

- Article 48 : "Production Operation IUP is given by: a) regent / mayor if the mine site, the location of processing and refining, as well as the harbor are within one district / city; b) governor if the mining site, the location of processing and refining, as well as the port is located in the district / city differently after getting a recommendation from regents / mayors in accordance with the local laws and regulations; and c) Minister when the mine site, the location of processing and refining, as well as the port are in a different province after getting a recommendation from the governor and regent / mayor in accordance with the local laws and regulations. "

- Article 67 paragraph (1); "(1) The regent / mayor gave IPR mainly to local residents, both individuals and groups of people and / or cooperative."; Article 74 paragraph (1) or subsection (5) "(1) IUPK given by the Minister to consider the interests of the region."; "(5) IUPK holders referred to in paragraph (2) can be expressed in no mood to commercialize other minerals found that"

As the substance of the law in a criminal offense there are always elements of actions in a criminal act. Basic principles in criminal offenses is the principle of legality and principle culpability. The principle of legality in criminal law set out in the Criminal Code article 1, paragraph (1) that "(1) An act can not be convicted unless.

Formulation juridical legality principle this means that said to include criminal acts if the act contained in the statutory provisions. Meanwhile in Article 158 clearly Mining Act contained provisions "do mining without IUP, IPR or IUPK". In other words, it's a legal substance in article stated that mining operations without permission is a criminal offense.

A critical factor in the formulation of Article 158 see Mining Act is the licensing law as a means to qualify is classified as a criminal act or not. Pressure point in the article 158 is IUP, IPR and IUPK. Mining Business License (IUP) is expressed as a license to conduct mining business. ${ }^{5}$ More Mining Act states that the provision of mining is mining business activities in order to exploitation of mineral or coal which covers the general investigation, exploration, feasibility, construction, mining, processing and refining, transportation and sales, and post-mining. ${ }^{6}$ While understanding the People's Mining Permit is the permission to carry out mining in the mining areas and people with an area of limited investment. ${ }^{7}$ The Special Mining Business License (IUPK) a permit to carry out mining in a special mining permit area.

The process of criminal investigation mining without permission, Must be able to prove the offense either based on two principles of legality and culpability. If the previous description it is clear there are criminal provisions in article 158 Mining Act, the authors analyzed further culpability principle (principle of error) in the PETI mining case. The suspect obviously made a mistake because the quarrying of sand mining through not having permission.

In more detail Mining Act Article 158 if the authors describe elements include: 
1) The element of "Everyone" as the Subject of Law

2) The element of "conduct mining operations" as an element of the act

3) Without fitted with permission (without IUP, IPR or IUPK)

Thus the substance of the law formulated in Article 158 Mining Act has been quite effective as a means of proving the basic law of criminal cases of mining without permission.

PETI case above, according to the author although done in the land right suspection, but the provisions of Article 158 Mining Act remains a criminal offense in the absence permission in the mining business conducted by the suspects. So in this licensing law, the origin of criminal acts. As licensing law in the operation of the licensing process for private individuals or legal entities are arising from the strategies and techniques used by the government to control or control a variety of circumstances, namely to prohibit without written permission for melakukan any activities that want to be regulated or controlled by the government. In other words, through the permit system the authorities intervened into or over the course of a certain community activities. ${ }^{8}$

\section{2.. The findings of fact PETI in Wonosobo}

As the implications of the enactment of the Mining Act, then any form of mining contained in the Act entered region settings. As we know that the qualification of existing mining in Indonesia covering mine excavation A, B and C in the above case, including category $C$ ie mineral quarry sand and rock. However because of the nature of law as stipulated in the Act exhaustive then any type of mineral that is mined could include a criminal offense if it does not meet the provisions of the Mining Act.

The findings were unearthed important facts in the problem of PETI in Wonosobo to authors describe as follows:

- Licensing law in the public perception is not fully aware of the law as evidenced by the dredging of sand in the suspect's own land, but the suspect did not understand that although done on private land should be run with the permissions.

- The legal awareness suspects effect on their cooperation in the investigations on PETI mining case. The author found that the suspect was not present during the call the suspect.

\section{Closing}

\subsection{Conclusion}

Back to the initial question the author of the extent of PETI law enforcement effectiveness in Wonosobo, then through analysis and existing legal reasoning the authors conclude that PETI in Wonosobo, dominant species contain criminal offense mining excavation C. Moreover the effectiveness of law enforcement of PETI gain response unbalanced factor legal awareness of suspects, particularly the licensing law, which has implications for noncooperation suspects. 


\subsection{Suggestion}

The author suggests the socialization of law and public law for the voluntary movement of miners, so a realization that a legal substance in the Mining Act as a means of protecting the public with government and environmental sustainability.

\section{Bibliography}

[1] Ahmad Redi "Dilema Penegakan Hukum Penambangan Mineral dan Batubara Tanpa Izin pada Pertambangan Skala Kecil (Dilemma of Law Enforcement in Small Scale Illegal Mining)" Jurnal Rechts Vinding Media Pembinaan Hukum Nasional $\begin{array}{lllll}\text { Volume } & 5 & \text { Nomor } & 3 & \text { (2016) }\end{array}$ http://rechtsvinding.bphn.go.id/artikel/ART\%207\%20JRV\%205.3\%20 WATERMARK.pdf.

[2] Polisi Report No P/A/445/IX/2017/Jateng/DIT Reskrimsus on 25 September 2017 on Suspection of Mining Without Permission (PETI).

[3] Prajudi Atmosudirdjo 1981 Hukum Administrasi Negara Ghalia Indonesia,

[4] The Act of Republic of Indonesia of 1945

[5] Act No. 4 of 2009 on Mineral and Coal Mining

[6] Yin Robert K 1994 Case Study Research,Thousand Oaks London New Delhi: Sage Publications 